\title{
Between Heterodox and Sunni Orthodox Islam: The Bektaşi Order in the Nineteenth Century and Its Opponents
}

\author{
Butrus Abu-Manneh \\ University of Haifa, Israel \\ butrus@research.haifa.ac.il
}

\begin{abstract}
In the first quarter of the nineteenth century Ottoman society, especially in cities suffered from a dichotomy. On the one hand there existed for several centuries the Bektaşi which was heterodox order. But in the eighteenth century there started to expand from India a new sufi order: the Naqshbandi - Mujaddidi order known to have been a shari'a minded and highly orthodox order. The result was a dichotomy between religious trends the clash between which reached a high level in 1826. Following the destruction of the janissaries, the Bektaşi order lost its traditional protector and few weeks later was abolished. But a generation later it started to experience a beginning of a revival and by the mid 1860 os it started to practice unhindered. But after the rise of Sultan Abdülhamid II (in 1876) the Bektaşis were again forced to practice clandestinely. However, they supported Mustafa Kemal in the national struggle.
\end{abstract}

\section{Keywords}

The Bektaşi order - Naqshbandi-Mujaddidi - Ali Paşa - Fuad Paşa - Sultan Abdulhamid II - Bektaşi revival

Throughout its long history the Bektaşi order contributed considerably to the Ottoman empire which was, as is known, a multi-national and multidenominational state. It remained unchallenged by other orders for over three centuries. However, it started to encounter a socio-religious hostility of a newly expanded order which reached the Ottoman lands from India at about the end of the seventeenth and the early eighteenth centuries, as we shall see hereafter. 
The religious life of the Muslim population in the Ottoman lands, particularly among the Turkish speaking communities, found a large degree of expression in the context of Sufi orders. These orders established tekkes (Sufi lodges) in Istanbul and in all the other Ottoman cities and towns. By the midnineteenth century, for instance, there existed in Istanbul alone about 250 such tekkes established by various order. ${ }^{1}$

Some of these orders spread in many Muslim countries like the Qadiri or the Rifa'i or of late the Naqshbandi (Nakşibendi) and others. Other orders, however, like the Mevlevi or the Halveti spread largely among the Turkish speaking communities, though the Halveti order started to expand from the Ottoman occupation of Egypt, and in the eighteenth century it became popular in Egypt among the Egyptian people. ${ }^{2}$ Of these orders, the Bektaşi spread almost wholly among the Turkish population. However it found many adherents in Albania and in other regions of the Balkans. ${ }^{3}$

On the whole, the Sufi orders kept within the framework of orthodox Islam except for the Bektaşi. As was known it was a heterodox order. Its beliefs were eclectic. ${ }^{4}$ Among these beliefs we find certain Shamani tenets. It also carried many Shi'ite precepts and incorporated certain Christian rites. Moreover, devotees of this order ignored performing the Sunni prayers. In the Bektaşi order "namaz yok niyaz var" (there is no prayer but supplication) wrote Besim Atalay. ${ }^{5}$ Thus, instead of performing the regular Sunni prayers in mosques

1 Anderson, Samuel "Dervish orders of Constantinople", The Muslim World, 12/1 (1922), pp. 53, 59. See also Barnes, John Robert, "The Dervish orders in the Ottoman empire", in The Dervish Lodge, ed. Raymond Lifchez (Berkeley: University of California Press, 1992), pp. 33-48; Ocak, Ahmet Yaşar, Perspectives and Reflections on Religious and Cultural Life in Medieval Anatolia (Istanbul: The Isis Press, 2012), pp. 84-94; Şehsuvaroğlu, Haluk, Asırlar Boyunca İstanbul (Istanbul: Cumhuriyet Gazetesi Tarafindan Hazirlanmiştir: n.d.), "Istanbul Tekkeleri”, pp. 209-11.

2 For the Halveti order in Syria and Egypt, see De Jong, F. "Khalwatiyya", in Encyclopaedia of Islam, $2^{\text {nd }}$ edition, ed. P. Bearman, Th. Bianquis, C.E. Bosworth, E. van Donzel and W.P. Heinrichs [hereafter $\mathrm{EI}^{2}$ ], vol. IV, pp. 991-3; Trimingham, J. Spencer, The Sufi Orders in Islam (Oxford: Oxford University Press, 1998), pp. 76-7.

3 Besim Atalay, Bektaşilik ve Edebiyatı (Istanbul, Matbaa-i Amire, 1340 [1921-2]), p. 5; Baha Said, Türkiye'de Alevi-Bektaşi, Ahi, ve Nusayri Zümreleri, ed. İsmail Görken (Ankara: Kültür Bakanlığı, 2000), see pp. 202-3 and 212; Küçük, Hülya, The Role of the Bektashis in Turkey's National Struggle (Leiden: Brill, 2002), p. 16.

4 İnalcık, Halil The Ottoman Empire The Classical Age (London: Weidenfeld and Nicholson, 1973), pp. 197-8; Melikoff, Irene, Sur les traces du soufisme turc: recherches sur l'Islam populaire en Anatolie (Istanbul: Isis, 1992), pp. 22, 59.

5 Besim Atalay, Bektaşilik ve Edebiyatı, p. 14; see also Birge, John K. The Bektashi Order of Dervishes ( $2^{\text {nd }}$. ed., London: Luzac, 1994), pp. 181 ff; Başbakanlık Osmanlı Arşivi, Istanbul 
they performed their religious ceremony called "Ayine-i Cem" in their ibadethane and behind closed doors. ${ }^{6}$ These rituals summarized the problem that the ulema and the Sunni orthodox upper classes especially the devotees of the Nakşibendi-Müceddidi order deplored. Obviously, the followers of the Bektaşi order were against performing the obligations and duties of Sunni orthodox Islam as required of Sunni orthodox Muslim believers.

Moreover, while the Sunni Muslim prayers are carried out in Arabic the ceremony of the Bektaşis, was performed in Turkish. "The Turkish national ideal was never able to find expression in the Arab internationalism, but it did find it in the tekkes of the Bektashis" wrote Baha Said in the early twentieth century. ${ }^{7}$ Referring to this, Atalay concluded that the language, literature and culture of the Bektaşi order were Turkish. ${ }^{8}$ The late Irene Melikoff confirmed that and added the Bektaşi order was a Turkish phenomenon. ${ }^{9}$ In addition, the Bektaşis recognized none of the four Sunni legal schools and followed the Mezheb-i Caferi, i.e. the Shi'a legal school. ${ }^{10}$

Though the structure of the Bektaşiya was that of a Sufi order, it also carried the characteristics of a popular socio-religious movement. It was moreover of a libertarian character and tolerant towards believers of other religions. As such it served the Ottoman sultanate in various ways. ${ }^{11}$ According to Halil İnalcık the eclectic nature of this popular order made Islam acceptable to many peasants in the Balkans $s^{12}$ and Suraiya Faroqhi, is of the opinion that it served as an agent of "assimilation and acculturation" of the Kızlbaş communities in Anatolia with the intention of "reintegrating [them] into the Ottoman polity".13

[hereafter воА], Mühimme Defterleri, no. 242, belge 476, f. 145, evasıt-ı Muharrem, 1242 (14-24 August, 1826); see also воA, Hatt-1 Humayunları, no. 17322 and no. 17351.

Hasluck, F.W., Christianity and Islam under the Sultans (Oxford: Claendon Press, 1929), 2 vols, vol. I, p. 165; Uzunçarşılı, İsmail H., Osmanlı Devleti Teşkilatından Kapukulu Ocakları, vol. I (Ankara: Türk Tarih Kurumu Basımevi, 1943), "Bektaşiler ve Bektaşi Tekkeleri hakkindaki Karar", pp. 566-75.

7 Said, Türkiye'de Alevi-Bektaşi, Ahi, ve Nusayri Zümreleri, pp. 202-3.

8 Birge, The Bektashi Order of Dervishes, p. 16.

9 Melikoff, Sur les traces du soufisme turc, p. 21.

10 Oytan, M. Tevfik, Bektaşiliğin İçyüzü, 2 vols. (Istanbul: Işık Basım ve Yayınevi, 1945-7), vol. II, p. 11; Besim Atalay, Bektaşilikve Edebiyatı, p. 4; Birge, The Bektashi Order of Dervishes, p. 99 .

11 Hasluck, Christianity and Islam under the Sultans, I, p. 166.

12 İnalcık, The Ottoman Empire The Classical Age, p. 197.

13 Faroqhi, Suraiya "Conflict, accommodation, and long-term survival: the Bektashi order and the Ottoman state (sixteenth-seventeenth centuries)", in Bektachiyya, ed. Alexandre Popovic and Gilles Veinstein (Istanbul: Isis, 1995), pp. $180 \mathrm{ff}$. 
Moreover, its pluralistic character contributed to harmonious relations among communities in Istanbul and in other Ottoman cities, ${ }^{14}$ MacFarlane adding that they were "Musulmans" except in name..$^{15}$

Not less important was the historical association between the Bektaşis and the Janissaries who were called the sons of Hacı Bektaş. As is known a Bektaşi Baba, (vekil), a representative of Hacı Bektas resided in the barracks of the $94^{\text {th }}$ Orta (regiment) of the Janissaries in Istanbul since the early sixteenth century. ${ }^{16}$ These close relations which extended for over three centuries provided the Bektaşis with protection and were at the basis of their cooperation with the Janissaries in socio-political events. ${ }^{17}$

For several centuries the presence of the Bektaşi order in Istanbul had been modest. Until the later decades of the eighteenth century they seem to have had five tekkes only. But by the first quarter of the nineteenth century their tekkes increased to 14 which indicates that the number of its followers in the city increased as well, perhaps to an unprecedented level. To quote Halil İnalckk again "at the beginning of the nineteenth century [it was estimated that] one fifth of the population of Istanbul [presumably of the Muslims] were Bektashis and they had fourteen tekkes",18 which was a sign that an expansion of the order in Istanbul had taken place in the last decades of the eighteenth and of the early nineteenth centuries.

\section{The Naksibendi-Müceddidi Order and Its Expansion into Istanbul}

It is suggested that the growth of the Bektaşi order in Istanbul in the late eighteenth century and early nineteenth occurred partly as a reaction to the expansion from India into the city of a young and vigorous order namely the Nakşibendi-Müceddidi order. This order which emerged as a reaction to other Sunni orthodox formations in that land was more demanding than the Sunni orthodox Islam in the countries of western Asia. As for the Bektaşi order, despite its heterodox beliefs it encountered until then no challenges from other orders or from socio-political formations. One reason for that was perhaps the

\footnotetext{
14 İnalcık, The Ottoman Empire The Classical Age, p. 197.

15 MacFarlane, Charles, Turkey and its Destiny, 2 vols. (London: Murray, 1850), vol. I, pp. 504-7.

16 Birge, The Bektashi Order of Dervishes, pp. $74 \mathrm{ff}$.

17 Concerning other relations see Ahmed Cevdet, Tarih-i Cevdet, $2^{\text {nd }}$. ed. (Istanbul: Matbaa-i Osmaniye, 1309 [1893-4]), vol. XII, p. 80.

18 İnalclk, The Ottoman Empire The Classical Age, p. 199.
} 
protection of the Janissaries whom they were connected with. But this situation started to change in the later decades of the eighteenth century apparently after that the Nakşibendi-Müceddidi order started to take root in Istanbul.

The founder of this branch of the Nakşibendi order was Sheikh Ahmad Sirhindi (d. 1624) in the early seventeenth century in India. Sirhindi distinguished the adherents of the order by stating that "the way of the Naqshbandis is absolutely identical with that of the Companions [of the Prophet] and they have the same rank". ${ }^{19}$ This statement frequently repeated in the Nakşibendi literature put these adherents in a special category and made joining the order a privilege. But at the same time it put upon those adherents moral and religious obligations towards themselves and towards the community. In other words, the followers of Sirhindi were entrusted with a mission and that was to bring Muslim believers to observe strictly the moral and religious commands of Islam and to lead a life according to the Sunna of the Prophet. In addition they were required to restore the sharia into the centre of the life of Muslim believers and to bring rulers to abide by its precepts. Due to the teaching of such ideals Sirhindi's disciples nick-named him "Mujaddid", renovator of the second millennium of Islam, hence his branch of the order was called the Naqshbandiya-Mujaddidiya.

Two main waves of this order reached Istanbul around the turn of the eighteenth century carried by two sheikhs who came originally from Bukhara or from its vicinity and who were trained in India by Sheikh Muhammad Ma'sum, Sirhindi's son and successor. The first wave was brought by Sheikh Murad alBukhari (d. 1132/1720 in Istanbul) ${ }^{20}$ and the second by the disciples of Sheikh Ahmad Curyani (also called Yekdest) (d. 1119/1707 in Mecca) who, after having been trained in India settled in Mecca from where his Turkish disciples carried the order to Istanbul. His leading deputy there was Sheikh Mehmed Emin Tokadi (d. 1158/1745). ${ }^{21}$ In Istanbul those emissaries spread the teaching of their

19 Friedmann, Yohanan, Shaykh Ahmad Sirhindi: an Outline of his Thought and the Study of his Image in the Eyes of Posterity (Montreal: McGill University, Institute of Islamic Studies, 1971), p. 68; Ter Haar, J.Q.J., Follower and Heir of the Prophet, Shaykh Ahmad Sirhindi (d. 1624) as Mystic (Leiden: Het Oosters Instituut, 1992).

20 On Sheikh Murad al-Bukhari see my article, "Sheikh Murad al-Bukhari and the expansion of the Naqshbandi-Mujaddidi order in Istanbul", Die Welt des Islams, 53/1 (2013), 1-25.

21 On the spiritual chain of Sheikh Ahmad Curyani in Istanbul see Şimşek, Halil İbrahim, Osmanlida Müceddidilik XII/XVIII Yüzyil (Ankara: Suf Yayınları, 2004), pp. 169-237; Şimşek, Halil İbrahim, Emin-i Tokadi Hayat-i ve Risaleleri (Istanbul, İnsan Yayınları, 2005); see also Mehmed Tevfik, Mecmüatü't-Teracim, Ms., Istanbul University Library, no. TY 192, f. $70 a$. 
Indian trained master. In other words a strict brand of Sunni orthodox Islam started to gain adherents in Istanbul and other cities in the eighteenth century.

\section{The Upper Classes and the Nakşibendi-Müceddidi Order}

Of these adherents we find many ulema, bureaucrats and literati. ${ }^{22}$ The humiliating treaty of Karlowitz (1699) which followed a long war with the Habsburg empire, or the defeat in war with Russia which ended similarly in the humiliating treaty of Küçük Kaynarca (1774), as well as the uncontrolled and undisciplined Janissaries, ${ }^{23}$ created a feeling of weakness among the Ottoman elite. Such a feeling induced them to find refuge in religion. In other words, the feeling of weakness may have contributed to the expansion of the NakşibendiMüceddidi order and the favourable acceptance of its şeyhs and emissaries among the upper echelons in the city. ${ }^{24}$

These developments show that about the turn of the century the NakşibendiMüceddidi order came to occupy a noted place in Istanbul despite its late arrival. ${ }^{25}$ Its teachings spread out, not only among the upper echelons of the Muslim community but also it penetrated palace circles and left its mark on sultans. Selim III (r. 1789-1807), for example, had as a tutor at the court of his father Mustafa III (r. 1757-1774) a highly learned alim, Hamidizade Mustafa who was known to be a follower of the Nakşibendi order and who later on under Selim was appointed şeyhülislam. ${ }^{26}$ Moreover, we find Sultan Abdülhamid I (r. 1774-1789), who was known to have been of deep religious belief ("dindar") and who was described by the historian Mustafa Nuri as "endowed with God fearing and piety" (vara' ve takva ile muttesif), ${ }^{27}$ cherishing much reverence for a Nakşibendi-Müceddidi şeyh named Geredeli Halil Efendi, to such a degree that when the şeyh passed away in 1784 , the sultan himself attended the funeral

22 See Süleyman Faik Efendi, Mecmua, Istanbul University Library, no. TY 9577, fols. 4a-b.

23 See my article "From conquering sultan to sultan-caliph: Sunni Orthodox Islam and the state in Istanbul in the eighteenth century", in Ötekilerin Peşinde Ahmet Yaşar Ocak'a Armağan, ed. Mehmet Öz and Fatih Yeşil (Ankara: Timaş Yayınları, 2015), pp. 452-6.

24 Ahmed Lütfi, Tarih-i Lütfi (Istanbul: Matbaa-yi Amire, 1290), vol. I, p. 285; Süleyman Faik Efendi, Mecmua, f. 4a-b.

25 Muslu, Ramazan, Osmanlı Toplumunda Tasavvuf 18 Yüzyıl (Istanbul: İnsan Yayınları, n.d.), pp. 232-309.

26 On Hamidizade Mustafa see Rifat Efendi, Devhatül-Meşayi (n. p.: no p., 1219 [04]), pp. 114-15; Ilmiye Salnamesi: Meşihat-i Çelile-i İslamiyenin Ceride-i Resmiyesine Mülhakdır ([Istanbul]: Matbaa-i Amire, 1334 [1915 or 1916]), pp. 562-3.

27 Mustafa Nurı, Netayic ül-Vukuat, 2nd ed. (Istanbul: Uhuvvet Matbaası, 1327), vol. IV, p. 22. 
prayers for him in the Mosque of Fatih, incognito. ${ }^{28}$ However, Ekrem Işık, a contemporary expert on Sufisim in Istanbul, suggested in his entry on "Tarikatlar" that the sultan was a Nakşibendi though the historian Ahmed Ata says that he had a leaning towards the Mevlevi order. ${ }^{29}$ But having a leaning towards the Nakşibendi order seems to have been his distinguishing characteristic. In other words it is perhaps possible to state that in the second half of the eighteenth century the Nakşibendi-Müceddidi order had taken root in Istanbul. As an indication of this, we find a number of şeyhülislams who were adherents of this order. Prominent among these we have mentioned Hamidizade Mustafa. Another we find is a highly respected alim, Veliyüddin Efendi who served during the sultanate of Mustafa III for seven years as şeyhülislam. ${ }^{30}$ It is not appropriate to enumerate them all here but one at least who served in the time of Sultan Selim III for about four years is worth mentioning. This was Salihzade Ahmed Esad. Ahmed Efendi was an enthusiastic partisan of the Nizam-ı Cedid to such an extent that certain Janissaries nick-named him the Nizam-ı Cedid Şeyhülislam. ${ }^{31}$ These şeyhülislams cover almost half of the reign of Selim III.

In the light of this we can perhaps understand why during Sultan Selim's reign the cadets of the Nizam-ı Cedid were subjected to the teachings of Sunni Islamic tenets. In the regulations (kanunname) issued in 1207 (1792-93) for the troops of the Nizam-ı Cedid in the barracks of Levent Çiftliği, they were subjected to learning the 'catechism' of Birgivi (Risaleyi Birgivi) who was an alim of the late sixteenth century known for his puritanical beliefs. ${ }^{32}$ Thus, when a government printing press was founded in Üskudar in 1802, 1,000 copies of the

28 Tayyarzade Ahmed Ata, Tarih-iAta (Istanbul:Yahya Efendi Matbaası and Basiret Matbaası, n.d.), vol. I, p. 214; Sarıcaoğlu, Fikret, Kendi Kaleminden Bir Padişahın Portresi, Sultan Abdülhamid I (Istanbul: Tatav, Tarih ve Tabiat Vakfi, 2001), p. 51; Muslu, Osmanlı Toplumunda Tasavvuf 18 Yüzyll, p. 241.

29 Tayyarzade Ata, Tarih-i 'Ata, I, p. 214; Tekeli, İlhan and Nuri Akbayar, Dünden Bugüne Istanbul Ansiklopedisi, vol. viI (Istanbul: Türkiye Ekonomik ve Toplumsal Tarih Vakfi, 1994), p. 216; Altunsu, Abdülkadir, Osmanlı Şeyhülislamları (Ankara: Ayyıldız Matbaası, 1972), p. 162.

30 On Veliuddin Efendi see Ilmiye Salnamesi, p. 534; Mehmet Süreyya, Sicill-i Osmani (Istanbul: Matbaa-i Amire, 1311[1893-1894), vol. IV, p. 614.

31 On Salihzade see Altunsu, Osmanlı Şeyhülislamları, pp. 169-70; Ilmiye Salnamesi, p. 569. Rifat Efendi, Devhatü'l-Meşayi, pp. 119-20.

32 On Birgivi see, Mehmet Süreyya, Sicill-i Osmanı, IV, p. 121; Mehmed Tahir, Osmanlı Müellifleri (Istanbul: Matbaa-i Amire, 1291-1293 [1874-1876]) vol. IV, pp. 253-6; Kufralı, Kasim, $E I^{2}$, II, p. 1235; Çavuşoğlu, Semiramis, "The Kadizadeli Movement: An Attempt of Şeri'at Minded Reform in the Ottoman Empire", Ph.D. Dissertation, Princeton University, 1990, pp. $48-54$. 
Risale were printed (1803) at the expense of Hatice Sultan, Selim's sister, for the teaching of the troops of the Nizam-ı Cedid. Two years later a second printing was issued for the same purpose. ${ }^{33}$ The instruction of Birgivi of the cadets of the Nizam-ı Cedid was a clear sign of the growing tendency among the ruling elite for Sunni orthodox precepts perhaps more than had been the case until then.

Other acts show that during Sultan Selim's reign the Nakşibendi-Müceddidi order enjoyed an influential position at the palace and in Istanbul in general. During his reign several new tekkes of this order were established by high ranking officials: one by the şeyhülislam Sammanizade Ömer Hulusi Efendi, a second by the grand vezir İzzet Paşa (served 1795-1798), a third by İbrahim Nesim, the kethüda, and a fourth at the Selimiye military barracks newly built in Üskudar, as well as several others.

No wonder then that we find among the close advisors of Sultan Selim III many dedicated Nakşibendi-Müceddidi adherents. Nine members out of 11 of the committee which the sultan established to counsel him on the Nizam-ı Cedid were disciples of Şeyh Bursalı Mehmed Emin, a leading şeyh of the order. ${ }^{34}$ Among these members there were İbrahim Nesim, the kethüda, Ahmed Faiz, the sultan's chief secretary, and Ahmed Bey, the defterdar of the treasury of the Nizam-ı Cedid, and other high ranking bureaucrats. ${ }^{35}$

This explains why the Janissaries did not halt at the dismantling of the Nizam-ı Cedid in 1807 but forced the sultan, before having him executed, to hand over to them his counselors who belonged to the leading NakşibendiMüceddidi circle of Şeyh Bursalı Mehmed Emin for execution. ${ }^{36}$ The şeyh himself was exiled to Bursa where he passed away a few years later, hence being named after that city. These events showed the weakness of the upper classes vis-à-vis the power of the Janissaries and their associates: the Bektaşis and the lower classes. Having been protected by the Janissaries, this power was translated by the Bektaşis into strengthening their position in the city as we have seen above. ${ }^{37}$

33 Cabi Ömer Efendi, Cabi Tarihi, 2 vols. ed. Mehmed Ali Beyhan (Ankara: Türk Tarih Kurumu Basımevi, 2003), vol. I, p. 9o; Ertuğ, Hasan Refik, Basin ve Yayın Hareketleri Tarihi (Istanbul: Yenilik Basımevi, 1970), pp. 126-7.

34 On Mehmed Emin Bursalı see my book Studies on Islam and the Ottoman Empire in the Nineteenth Century (1826-1876) (Istanbul: Isis, 2001), pp. 42-3; see Mehmed Şemseddin, Yadikar-ı Şemsi, (Bursa: Matbaa-i Vilayet, 1332 [1913]), pp. 172-8.

35 See the list of the names in my book, Studies, p. 43; Ahmed Asım, Tarih-i Asım (Istanbul, n.d.), 2 vols, vol. II, p. 83 .

36 Ahmed Asım, Tarih-i Asım, II, p. 83.

37 Cf. İnalcık, The Ottoman Empire The Classical Age, p. 199. 
In light of this we can perhaps conclude that at the turn of the nineteenth century two religious and cultural trends confronted each other in Istanbul: a Sunni orthodox, shari'a-minded trend led by Nakşibendi-Müceddidi adherents and a heterodox trend led by şeyhs of the Bektaşi order. However, it is suggested that it was not simply a religious conflict between two trends of Islam, but it carried also symptoms of class conflict between the upper and lower classes. In this conflict the former suffered from weakness. In other words, Ottoman Muslim society was suffering at the time of our discussion from a cleavage of two socio-religious trends antagonistic towards each other.

\section{The Bektaşi Order and the Khalidi Suborder in the Early Nineteenth Century}

The events of 1807 showed that the two waves of the Nakşibendi-Müceddidi order which started to spread into Istanbul at about the turn of the eighteenth century and gathered many adherents from among the upper echelons of society, could not gather enough power to counter their opponents led by the Janissaries. These events seem to have left the upper classes in Istanbul humbled and perplexed. But their reaction was soon to come. After about two decades it was noticed that these classes started to gather power which apparently came from a new wave of the Nakşibendi-Müceddidi order. This wave reached Istanbul towards the end of the second decade of the nineteenth century carried by deputies of Sheikh Khalid of Shahrizur in Iraqi Kurdistan.

Sheikh Khalid was initiated into the Naqshbandi-Mujaddidi order in India in the same way as his two predecessors of the early eighteenth century referred to above. ${ }^{38}$ His spiritual guide there was Shah Ghulam Ali (d. 1824) (also called Sheikh Abdullah al-Dihlawi) of New Delhi who was one of the highly respected Sufi guides of this order in India at the time, and whose spiritual chain went back to Sheikh Ahmad Sirhindi.

After his return from India in 1810, Sheikh Khalid settled in his hometown Sulaimaniya in northern Iraq and started to preach the teachings of the order there and in the region of Kurdistan. However, due to a conflict with a local sheikh of the Qadiri order, Ma'aruf al-Nudahi of long standing in the town, the adherents of Sheikh Khalid in Baghdad, themselves of Kurdish origin, called

38 See al-Haidari, Ibrahim Fasih, al-Majd al-Tālid fi Manaqib al-Shaikh Khalid (Istanbul, 1292 [1874]), pp. 32-38; al-Khani, Abdulmajid, al-Hadai'q al-Wardiyah fi Haqai'q Ajilla' al-Naqshbandiyah (Cairo, 1308 [1890-1]), pp. 226-30. 
him to the city and assisted him in establishing a Zawiya for himself there. ${ }^{39}$ But the insistence of Sheikh Khalid on following the shari'a in matters of society and state and his assertiveness in preaching the teachings of the order and for other reasons, made the in-coming governor general of Iraq, Davud Paşa, dislike his presence in Baghdad and arrange for his return to Sulaimaniya. Finally, despite the fact that he succeeded in recruiting many followers in Kurdistan, Sheikh Khalid preferred to leave Iraq altogether and settled in Damascus (about 1822$)^{40}$ where he passed away in 1827 .

The Naqshbandi-Mujaddidi order spread usually among the higher echelons of society. But many of the followers of Sheikh Khalid in the region of Kurdistan came from rural areas which distinguished the Khalidiya from the mother order. However, despite their social origin, Sheikh Khalid succeeded in training many disciples and deputies ${ }^{41}$ and imbibing them with Sunni orthodox ideals and with much zeal to spread them out. They carried the teachings of the order wherever he sent them. As mentioned above about 1819 he started sending emissaries to Istanbul who settled in the vicinity of the Mosque of Fatih. Given the situation in Istanbul described above, these emissaries succeeded in recruiting many adherents from among the population of the city in general and not only from among the upper classes. ${ }^{42}$ The political circumstances were conducive to its expansion there. On the one hand, the outbreak of the Greek Revolution in 1821 and the atrocities that accompanied it and the anger that it regenerated among the Muslim population and on the other the inability of the Janissaries to suppress it as a result of which their image was damaged in the eyes of the public. Moreover, the upper classes found in the teachings of the khalidi suborder a means for deepening Sunni Orthodox beliefs in the city. The result of such developments was to empower these classes in the face of the Janissaries and the Bektaşis.

To conclude, the expansion of the Khalidi suborder into Istanbul and the favourable attitude its message met with among the upper and the lower classes, empowered the anti-Janissary elements in the city. It also undermined what the Bektaşi order stood for and paved the way for its abolition.

39 al-Haidari, al-Majd al-Tālid, pp. 34-5.

40 al-Khani, al-Hadai'q al-Wardiyah fi Haqai'q Ajilla' al-Naqshbandiyah, pp. 231-2.

41 al-Haidari, al-Majd al-Tãlid, pp. 36, 71.

42 For Khalid's emissaries to Istanbul see Süleyman Faik Efendi, Местиa, fols. 4a-b; Gölpınarl, Abdülbaki, 100 Soruda Türkiye'de Mezhebler ve Tarikatlar (Istanbul: Gerçek Yayınevi, 1969), pp. 219-21. 


\section{The Abolition of the Bektaşi Order}

About four weeks after the destruction of the Janissaries in June 1826, a Hatt- $\iota$ Hümayun was issued which proclaimed the abolition of the Bektaşi order. Such a measure undoubtedly caused the highest satisfaction among the Nakşibendi-Müceddidi followers and especially among the adherents of its branch the Khalidi sub-order. We read in the Hatt that the tekkes of the order that were founded in the preceding 60 years were to be demolished. ${ }^{43}$ Nine such tekkes were destroyed in Istanbul. ${ }^{44}$ The other five tekkes were handed over to Nakşibendi-Müceddidi and Khalidi şeyhs, a sign of the role they played in bringing about this measure and of the power they came to enjoy in the city. Moreover, three leaders of the Bektaşis in Istanbul were put to death and many other leading members were sent to exile to Anatolian ${ }^{45}$ cities where Sunni orthodoxy was deeply rooted in order to expose them to Sunni orthodox ideals. ${ }^{46}$

Similarly, at the head of the central tekke of Hacı Bektaş in Kirşehir, a Nakşibendi-Müceddidi şeyh was installed instead of the attending şeyh, Hamdullah Çelebi Efendi, who was exiled to Amasya. ${ }^{47}$ Hamdullah Efendi was regarded as having been a descendent of Hacı Bektaş after whom the order was named.

In other words, by the expansion of the Khalidi suborder into Istanbul, the Nakşibendi-Müceddidi order experienced re-invigoration and was apparently transformed from an order that spread among the elite into a movement accepted by a much wider circles.

It was a socio-religious transformation. After the destruction of the Janissaries the Bektaşi order lost its protector and as mentioned above was abolished by a decree of the sultan and the silent approval of the other orders. ${ }^{48}$ This

43 Ahmed Cevdet, Tarih-i Cevdet, XII, p. 183; Aksan, Virginia H., Ottoman Wars 1700-1870: An Empire Besieged (Harlow: Longman/Pearson, 2007), pp. 322-5.

44 See Birge, The Bektashi Order of Dervishes, p. 77. The author provides the list of nine tekkes that were demolished.

45 Ahmed Cevdet, Tarih-i Cevdet, XII, p. 183, for the names of those şeyhs who were executed.

46 Ahmed Lütfi, Tarih-i Lütfi, I, p. 168, for the exile of the members of the Beşiktaş Cemiyet-i İlmiye. Other members of the Bektaşi order in Istanbul were exiled to Kayseri, Hadim, Birgi, Güzel Hisar and Tire, where Sunni Islam had deep roots, see also p. 151; Sahaflar Şeyhizade Esad Mehmed, Üss-i Zafer, 1st ed. (Istanbul, 1241/[1826]), p. $211 \mathrm{ff.}$

47 See воA, Mühimme Defterleri, Evahir-i Şaban 1242 (19-28 March 1827), pp. 231-2; Ahmed Lütfi, Tarih-i Lütfi, I, p. 235 .

48 No şeyh of the other orders opposed the abolition, see Sahaflar Şeyhizade Esad Mehmed, Üss-i Zafer, pp. 207-10. 
measure took place after several hundred years of existence and accommodation with the existing social order and after serving the state loyally throughout that period. ${ }^{49}$ Indeed, the abolition of the order left Ottoman society less tolerant, less liberal, and more dogmatic for the following decades.

\section{The Bektaşi Order: Eclipse and Revival}

As mentioned above, what distinguished the emissaries of Sheikh Khalid was their being assertive and even aggressive in spreading their teachings perhaps more than the other orders. Moreover, the attitude of Sheikh Khalid towards heterodox Islam and towards the Shi'ites and the non-Muslims was hostile, an attitude which he apparently inculcated in his disciples. ${ }^{50}$ In this sense Suraiya Faroqhi might not be far from the truth in suggesting that the abolition of the Bektaşi order "was a concession for the extreme representatives of the Muslim law (sheri'at) ... from among the ulema". ${ }^{51}$

In other words, for the next generation a strict brand of orthodox Islam occupied a dominant place in Istanbul in matters of society and state. Perhaps due to that many followers of the Bektaşi order hid their identity by practicing dissimulation (takiye). But towards the end of the 1840 s this situation started to experience a slow change. Charles MacFarlane, a British traveller who wrote an interesting book about his impressions of the socio-political life in Istanbul and other Ottoman cities in the later 1840 s, found that the Bektaşi order was experiencing a comeback first in Bursa and the area around it. ${ }^{52}$ Other travellers had a similar impression. ${ }^{53}$ However, at about the beginning of the 1850 s we find that Şahkulu Sultan Dergahı in Istanbul (also called Merdivenköy tekkesi) started to function openly. Within a short time several other Bektaşi

49 For the Bektaşi order serving the state and the community see Küçük, The Role of the Bektashis in Turkey's National Struggle, p. 19; Ocak, Ahmet Yaşar, "Bektaşilik", in TDV İslam Ansiklopedisi, vol. v, p. 378.

5o The attitude of Sheikh Khalid towards the non-Muslims, the Shi'ites, and the Persians was hostile, see Sahib, As'ad, Bughyat al-Wajid fi Maktubat Mawlana Khalid (Damascus: Matba'at al- Taraqi, 1334 [1915-6]), p. 24. воA, Mühimme-i Mektum, vol. X, pp. 47-57, 4 Şaban 1284 (3 December 1867); Faroqhi, "Conflict, accommodation and long time survival", p. 180; Melikoff, "Le probleme Kizilbaş", in Sur les traces du soufisme turc, pp. 29-43, see especially pp. 32-3. For the comeback of the Bektaşi order, see MacFarlane, Turkey and its Destiny, I, pp. 496-507.

53 For other travellers' similar impression see Birge, The Bektashi Order of Dervishes, p. 79. 
tekkes resumed their activities. But from about the mid 1860s, and according to Rifki Baba, ${ }^{54}$ the order seems to have begun enjoying a freedom of activity openly which suggests a relaxation of the official policy towards it as we shall see below. As mentioned above it should be emphasized that the followers of the Bektaşi order were largely of Turkish origin ${ }^{55}$ which meant a rejection of Islamic internationalism as represented by the Nakşibendi-Müceddidi and other orders and opting for a Turkish brand of Islam.

\section{The Bektaşi Order in the Later Tanzimat Period}

The outbreak of the Crimean War (late in 1853 - early 1856) discredited the old ruling class and a new stratum came forward to control power at the Sublime Porte. Ali and Fuad Paşas, who led this new stratum, opened a new phase of reform. Partly under the influence of the foreign powers, the allies of the Ottomans in the war, they proclaimed in February 1856 the Islahat Firman (the Reform Edict) which granted legal and civil equality to the non-Muslims with the Muslims. ${ }^{56}$ As is known, this measure which contradicted the shari'a, aroused the resentment of many Sunni Orthodox Muslims who regarded it as a departure from the precepts of the sharia and the principles of the Muslim state, contrary to the Hatt- $\iota$ Serif of Gülhane of November 1839 which was rooted in Sunni Islamic ideals. ${ }^{57}$ The historian Ahmed Cevdet for instance, wrote that many Muslims began to grumble that "Aba ve ecdadımızın kaniyle kazanılmış olan hukuk-ı mukaddese-yi milliyetimizi bu gün gaib ettik... Ehl-i Islama bu bir ağlayacak ve matem edecek gündür".58 [Our sacred national rights that our ancestors gained with their blood, have been lost today ... It is a day of tears and mourning for the Muslims]. Even Mustafa Reşid attacked Ali and Fuad and accused them "of going too far and too fast in granting political privileges

54 Ahmet Rıfkı Baba, Bektaşi Sırrı, 2 vols. (Dersaadet: Bekir Efendi Matbaası, 1325 [19o9]), see vol. I, pp. 147-8; Birge, The Bektashi Order of Dervishes, p. 80.

55 See Atalay, Bektaşilikve Edebiyatı, p. 5 .

56 On the Reform Edict of 1856 see Badem, Candan, The Ottoman Crimean War (1853-1856) (Leiden: Brill, 2010), pp. 343-5; Findley, Carter Vaughn, Turkey, Islam, Nationalism and Modernity A History 1789-2007 (New Haven: Yale University Press, 2010), pp. 99-100 for the reaction of conservative Muslims.

57 See my article "The Islamic roots of the Gülhane Rescript", Die Welt Des Islams, 34 (1994), 173-203.

$5^{8}$ Ahmed Cevdet, Tezakir (vol. 1, nos. 1-12) ed. Cavid Baysun (Ankara: Türk Tarih Kurumu Basımevi, 1953), pp. 67-8. 
for the non-Muslims. Muslims are grieved and sad" and added that a change should be gradual and without foreign intervention. ${ }^{59}$

In other words, Ali and Fuad Paşas and their associates adopted a reform programme different from what was followed in the first period of the Tanzimat, primarily towards the non-Muslims which was followed by their predecessors even though it contradicted the sharia. The fact that many thousands of British and French troops, the allies of the Ottomans in the war, were still in the vicinity of Istanbul allowed Ali and Fuad to ignore the resentment of Sunni Muslim public opinion. ${ }^{60}$

More serious than the reaction of Cevdet and Mustafa Reşid was a conspiracy against Ali and Fuad and even against Sultan Abdülmecid which was uncovered in 1859. Its members called themselves the Fidailer Cemieyti (Society of Zealots), but the authorities called it the Küleli affair after the name of the citadel where they were incarcerated. It was founded and led by Şeyh Ahmed el-Süleymani of the Nakşibendi-Halidi suborder who was also of Kurdish origin. But other Suf şeyhs joined him in addition to military officers and certain high ranking officials. The cause behind it, as its leader told his interrogators, was "the question of [granting] equal rights" for the non-Muslims. He added "my wish is to have the shari'a precepts carried out". ${ }^{61}$

However, this secret society appears to have had several hundred sympathizers in Istanbul mostly clandestinely. ${ }^{62}$ But the resentment of the Muslim public did not deter Ali and Fuad from applying new measures. It was perhaps one of the reasons which led them to establish modern governmental institutions and apply laws borrowed from western systems while contradicting or ignoring shari'a precepts. Such institutions provided the state with much coercive power that it did not possess before. In such a modernized state the citizen stood in direct relations with the state apparatuses unprotected by sacred and durable laws like shari'a precepts and deprived of middlemen through which the power of the state was filtered, as were the norms in the Muslim

59 See the Memo of Mustafa Reşid in Ahmed Lütfi, Tarih-i Lütfi, IX, especially p. 247.

6o For the Küleli Affair see Iğdemir, Uluğ, Küleli Vak'ası Hakkinda Bir Araştirma (Ankara: Türk Tarih Kurumu Basımevi, 1937); see also Ziyad Ebüzziya, Şinasi, ed. Hüseyin Çelik (Istanbul: İletişim, 1997), pp. 155-64; Kuran, Ahmed Bedevi, Osmanlı İmparatorluğunda Inkilap Hareketleri ve Milli Mücadele (Istanbul: n.p., 1956), pp. 49-53.

61 İsmail Habib [Sevük], Türk Teceddüd Edebiyatı Tarihi (Istanbul: Matbaa-ı Amire, 1340 [1924]), p. 421.

62 As stated in the text Ali and Fuad controlled the Sublime Porte and reorganized the state institutions to fit the new political circumstances. 
state. The reaction to these measures was the growing of opposition to them spearheaded by orthodox Islamic believers.

Given such a background we can possibly understand why the attitude towards the Bektaşi order was relaxed by the Porte in the late Tanzimat period. One aspect of this policy was the reopening, especially from the 186os, of the old Bektaşi tekkes without restriction. ${ }^{63}$ Moreover, it seemed necessary to counter the opponents of their policy among whom we find the Young Ottomans and others, who were active from about this time ${ }^{64}$ It was claimed, however, that the mother of sultan Abdülaziz extended protection to the Bektaşis. ${ }^{65}$ But the truth was that while the Porte was interested in the renewed activity of the Bektaşis, and for the same reason, of the Mevlevis, ${ }^{66}$ the NakşibendiMüceddidi adherents opposed that.

During this time some literary books were published by the Bektaşis especially of poetry and hymns. Many ulema were shocked at their renewed activity and one of them, Harputlu İshak Efendi published a book entitled Kaşif ül-Esrarve Dafi ül-Eşrar (1288/[1871]) which was an attack on the Bektaşis. Moreover, a second edition of Sahhaflar Şeyhizade Esad, Ussi Zafer, first published in 1826 was republished. As is known, this book gave an account of the destruction of the Janissaries and of the abolition of the Bektaşi order. A few years later came a response written by Ahmed Rifat and entitled Mir'at-ul alMakasid fi Def'ial-Mefasid (Istanbul,1293[1876]).

However, during the reign of Sultan Abdülhamid II (throughout which publications were subjected to censorship), there were no references to Bektaşi publications. Finally, a large number of Bektaşis supported Mustafa Kemal in the national struggle for Turkey's independence and for the abolition of the Caliphate. ${ }^{67}$

63 Ahmet Rıfkı Baba, Bektaşi Sırrı, I, pp. 147-8; See my Studies, p. 135.

64 For the reaction of the Young Ottomans see Mardin, Şerif, The Genesis of Young Ottoman Thought: a Study in the Modernization of Turkish Political Ideas (Princeton, N.J.: Princeton University Press, 1962); see also Zurcher, Erik J., "The Ottoman empire 1850-1922: unavoidable failure?", in Zurcher, Erik J., The Young Turk Legacy and Nation Building (London: I.B. Tauris, 2010), pp. 59-72.

65 For the favour of the mother of Sultan Abdülaziz towards the Bektaşis see Birge, The Bektashi Order of Dervishes, pp. 80-1; see also my Studies, p. 137.

66 See воA Dahiliye Iradeleri no. 22004 (dated 26 Rebiülahir 1272/5 January 1856); for the Porte and the Mevlevi order see Mehmed Ziya, Yeni Kapu Mevlevihanesi, (Istanbul, 1329 [1911]), pp. $177 \mathrm{ff}$.

Küçük, The Role of the Bektashis in Turkey's National Struggle, pp. 125-50. 


\section{Conclusion}

What happened in June and July 1826 in Istanbul was a turning point in the religious and socio-political life of Ottoman society. As mentioned above Ottoman society was suffering in the late eighteenth and in the nineteenth centuries from a cleavage between two trends in opposition to each other. The first the Bektaşi order which had carried heterodox beliefs and most of whose members belonged to the Turkish speaking population. The other, namely the Nakşibendi-Müceddidi order had expanded lately from India. Being shariaminded it called for observing high Sunni orthodox ideals. In addition to expanding into Ottoman lands it had followers in many Muslim countries in Asia. As we have seen it exercised, especially after the expansion of its branch the Khalidi suborder, much influence in Istanbul and in the Anatolian cities. Indeed, its impact on the social and political life in these cities was most significant primarily in the first few decades of the nineteenth century.

After the destruction of the Janissaries in June 1826, the Bektaşi order lost its traditional protector and was abolished a few weeks later which symbolized the success of the upper classes represented by the Nakşibendi-Müceddidi order and by the Islam it represented. It also changed the ethos of the state. ${ }^{68}$ In a sense Ottoman society became less tolerant and less pluralistic as the first period of the Tanzimat had shown.

Following its abolition many Bektaşi followers continued to exist clandestinely for about a generation before they resumed practicing openly again. Ali and Fuad Paşas who took control of the Sublime Porte at the end of the Crimean War tried to bolster the lower-middle and the lower classes from among which the Bektaşi order normally drew many of its followers. Indeed throughout the 1860 s and the first half of the 1870 s the Bektaşis enjoyed freedom of activity but following the death of Fuad Paşa in 1869 and of Ali Paşa in 1871 the religious and the socio-political antagonism between the above-mentioned two trends re-emerged. From then it took different shapes but this is an episode that requires a separate study.

68 See my article "The Islamic roots of the Gülhane Rescript", Die Welt des Islams, 34 (1994), 173-203. 